\title{
Oral cavity verruciform xanthoma - the importance of total excision - report of two
}

\section{cases}

\author{
Xantoma verruciforme de cavidade oral - a importância da excisão total - relato de dois casos \\ Xantoma verruciforme de la cavidad oral - la importancia de la escisión total - informe de dos casos
}

\author{
Alessandra de Aragão Almeida \\ ORCID: https://orcid.org/0000-0001-8446-888X \\ Universidade do Oeste Paulista, Brazil \\ E-mail: alessandraaragao@outlook.com \\ Camila de Souza Arantes \\ ORCID: https://orcid.org/0000-0003-2881-384X \\ Universidade do Oeste Paulista, Brazil \\ E-mail: camilaarantes_@hotmail.com \\ José Luiz Santos Parizi \\ ORCID: https://orcid.org/0000-0001-5032-1732 \\ Universidade do Oeste Paulista, Brazil \\ E-mail: parizi.patologia@unoeste.br \\ Gisele Alborghetti Nai \\ ORCID: https://orcid.org/0000-0003-1674-7371 \\ Universidade do Oeste Paulista, Brazil \\ E-mail: patologia@unoeste.br
}

\begin{abstract}
Verruciform xanthoma is a relatively rare epithelial hyperplasia found in the oral mucosa, usually in the gingiva, alveolar mucosa and hard palate. However, it can also affect the skin and genital mucosa. This study aims to describe two cases of verruciform xanthoma and the importance of total excision of this lesion. The patients are two Caucasian females, 58 and 23 years old. On clinical examination, both had a somewhat verrucous lesion on the lateral border of the tongue. Surgical excision of the lesions was performed. The specimens were sent for anatomopathological examination, which showed epithelium with discrete parakeratosis, irregular acanthosis with epidermal crest elongation and an accumulation of numerous xanthomatous macrophages in the connective tissue, diagnosed as verruciform xanthoma. One of the patients had compromised surgical margins, in whom the lesion recurred. Although it is an uncommon lesion, verruciform xanthoma should be considered in the differential diagnosis of verrucous (benign and malignant) lesions of the oral cavity, and total excision prevents the recurrence of this lesion.
\end{abstract}

Keywords: Xanthomatosis; Epithelium; Tongue; Biopsy; Mouth neoplasms.

\section{Resumo}

O xantoma verruciforme é uma hiperplasia epitelial relativamente rara encontrada na mucosa oral, geralmente na gengiva, mucosa alveolar e palato duro. No entanto, também pode afetar a pele e a mucosa genital. Este estudo tem como objetivo descrever dois casos de xantoma verruciforme e a importância da excisão total dessa lesão. Os pacientes são duas mulheres caucasianas, 58 e 23 anos. No exame clínico, ambos apresentavam lesão verrucosa na borda lateral da língua. A excisão cirúrgica das lesões foi realizada. As amostras foram enviadas para exame anatomopatológico, que mostrou epitélio com paraqueratose discreta, acantose irregular com alongamento da crista epidérmica e acúmulo de numerosos macrófagos xantomatosos no tecido conjuntivo, diagnosticados como xantomas verruciformes. Uma das pacientes apresentou margens cirúrgicas comprometidas, na qual a lesão recidivou. Embora seja uma lesão incomum, o xantoma verruciforme deve ser considerado no diagnóstico diferencial de lesões verrucosas (benignas e malignas) da cavidade oral, e a excisão total impede a recorrência dessa lesão.

Palavras-chave: Xantomatose; Epitélio; Língua; Biopsia; Neoplasias bucais.

\section{Resumen}

El xantoma verruciforme es una hiperplasia epitelial relativamente rara que se encuentra en la mucosa oral, por lo general en la encía, la mucosa alveolar y el palato duro. Sin embargo, también puede afectar la piel y la mucosa genital. Este estudio tiene como objetivo describir dos casos de xantoma verruciforme y la importancia de la escisión total de esta lesión. Los pacientes son dos mujeres caucásicas, de 58 y 23 años. Al examen clínico, ambos tenían una lesión verrugosa en el borde lateral de la lengua. Se realizó escisión quirúrgica de las lesiones. Las muestras fueron enviadas para examen anatomopatológico, las cuales mostraron epitelio con paraqueratosis leve, acantosis irregular con alargamiento de la cresta epidérmica y acumulación de numerosos macrófagos xantomatosos en el tejido 
conectivo, diagnosticados como xantomas verruciformes. Una de las pacientes tenía márgenes quirúrgicos comprometidos, en lo que la lesión recidivó. Aunque que sea una lesión infrecuente, el xantoma verruciforme debe considerarse en el diagnóstico diferencial de las lesiones verrugosas (benignas y malignas) de la cavidad bucal, y la escisión total evita la recurrencia de esta lesión.

Palabras clave: Xantomatosis; Epitelio; Lengua; Biopsia; Neoplasias de la boca.

\section{Introduction}

Verruciform xanthoma is a relatively rare epithelial hyperplasia, first described by Shafer in 1971 (Ryu et al., 2013). It can be found mainly in the oral cavity but also in the vulva, scrotum, penis, anal region and extremities, usually presenting as single lesions (Dorankula et al., 2013; de Andrade et al., 2015; Liddell \& Plantier, 2021). Disseminated lesions involving the mouth, genitals and skin are extremely rare (Tang et al., 2014).

The prevalence of oral verruciform xanthoma is estimated to be $0.025 \%$ to $0.094 \%$ in the world population (Ryu et al., 2013). The incidence rate is 0.025 to $0.05 \%$ of all cases of oral pathology (Hedge et al., 2013). Approximately 300 cases of oral verruciform xanthoma have been described in the literature (Belknap et al., 2020).

Oral verruciform xanthoma can occur in any age group, being more common between 40 and 60 years (Ryu et al., 2013). It has a higher incidence in men when it occurs in the age group below 50 years; however, the number of cases is higher in women when it occurs in individuals over 50 years (Dorankula et al., 2013; Hegde et al., 2013; de Andrade et al., 2015; Tamiolakis et al., 2018).

Verruciform xanthoma is usually diagnosed clinically as papilloma (Hedge et al., 2013), although it may present a broad clinical differential diagnosis with other verrucous (benign and malignant) lesions (Shahrabi Farahani et al., 2011; de Andrade et al., 2015).

Associations with trauma and an inflammatory reaction were proposed for xanthomas found in the buccal region. Genital xanthomas, in addition to infectious associations, are described in association with other diseases related to immunological disorders, such as psoriasis and pemphigus vulgaris (Hedge et al., 2013; Aggarwall et al., 2014; Marques et al., 2014). There are cases described in the literature of oral verruciform xanthoma in chronic graft-versus-host disease patients, both adults (Bar et al., 2021) and children (Jenkyn et al., 2020).

The current study aims to describe two cases of verruciform xanthoma, a rare entity of the oral cavity, and to present to the dental surgeon the importance of histopathological analysis in the diagnosis and the importance of total excision of this lesion.

\section{Methodology}

This is a descriptive, retrospective case report study. Case reports are important for disseminating knowledge about discovering new diseases, treatments, unexpected effects, side effects and for teaching (Kienle \& Kiene, 2009).

Both patients signed the Terms of Free and Informed Consent authorizing the disclosure of their clinical case histories. This report was approved by the Research Ethics Committee of Universidade do Oeste Paulista - CEP-UNOESTE $\left(\right.$ CAAE $n^{\circ}$ 68319417.4.0000.5515).

\section{Case Reports}

\subsection{Case 1}

A female patient, 58 years old, Caucasian, and a smoker since the age of 15 (currently 2 packs / day), attended the dental clinic reporting pruritus and burning of the tongue for five months. She reported that she had sought out various health 
professionals and had undergone various drug treatments without success. The patient denied systemic or immunological diseases. The patient has superior and inferior removable partial prostheses, with a metal frames and acrylic resin.

On clinical examination, the presence of a white-gray verrucous lesion was observed on the lateral border of the tongue, on the right, measuring approximately 1 and $4 \mathrm{~cm}$ in its smallest and largest diameters, respectively. The clinical diagnosis was leukoplakia.

Surgical excision of the lesion was performed, and the specimen was sent for anatomopathological examination. The product of the excision, on macroscopic examination, was described as a spindle of white mucosa, with a roughened and hardened surface. Under microscopy, histological sections showed epithelium with discrete parakeratosis, irregular acanthosis with elongation of the crests and an accumulation of numerous xanthomatous macrophages in the connective tissue (Figure 1A and 1B). Findings suggestive of human papillomavirus (HPV) infection, such as hypergranulosis or koilocytosis, were not observed in the initial biopsy. PAS (periodic acid-Schiff) staining showed diastase-resistant granules in the cytoplasm of the macrophages (Figure 1C). The diagnosis was compatible with verruciform xanthoma, with compromised surgical margins. 
Figure 1. Histological features of the initial tongue lesion-Case 1. A - Epithelium with irregular acanthosis and elongation of crests and proliferation of xanthomatous macrophages throughout the connective tissue to the surgical margins (hematoxylineosin, 40x magnification). B - Accumulation of numerous xanthomatous macrophages in the connective tissue (hematoxylineosin, 200x magnification). C - Note PAS-positive, diastase-resistant granules in the cytoplasm of macrophages (PAS with diastase, 100x magnification).

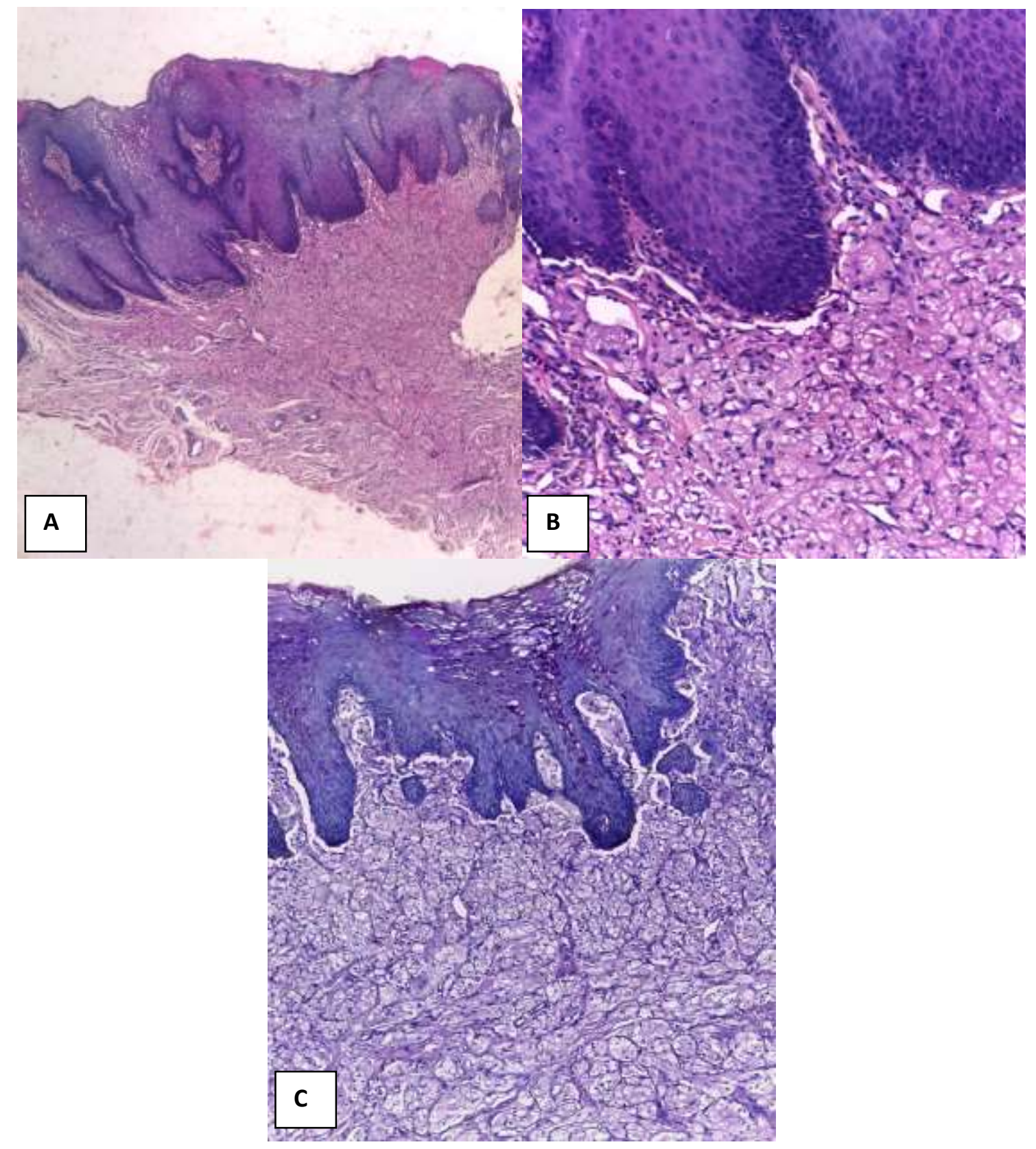

Source: Authors themselves.

Three years after lesion excision, the patient presented with a hardened nodule $0.4 \mathrm{~cm}$ in diameter at the same site as the previous lesion (Figure 2A). Resection of the new lesion was performed. The anatomopathological examination revealed many xanthomatous cells in the connective tissue, compatible with residual verruciform xanthoma with free surgical margins (Figure 2B and 2C). 
Figure 2. Second lesion of the tongue - Case 1. Clinical features: A - Note a nodule on the lateral border of the tongue (arrow). Histological features: B - Accumulation of numerous xanthomatous macrophages in the connective tissue (hematoxylin-eosin, 400x magnification). C - Note PAS-positive, diastase-resistant granules in the cytoplasm of the macrophages (arrow) (PAS with diastase, 400x magnification).

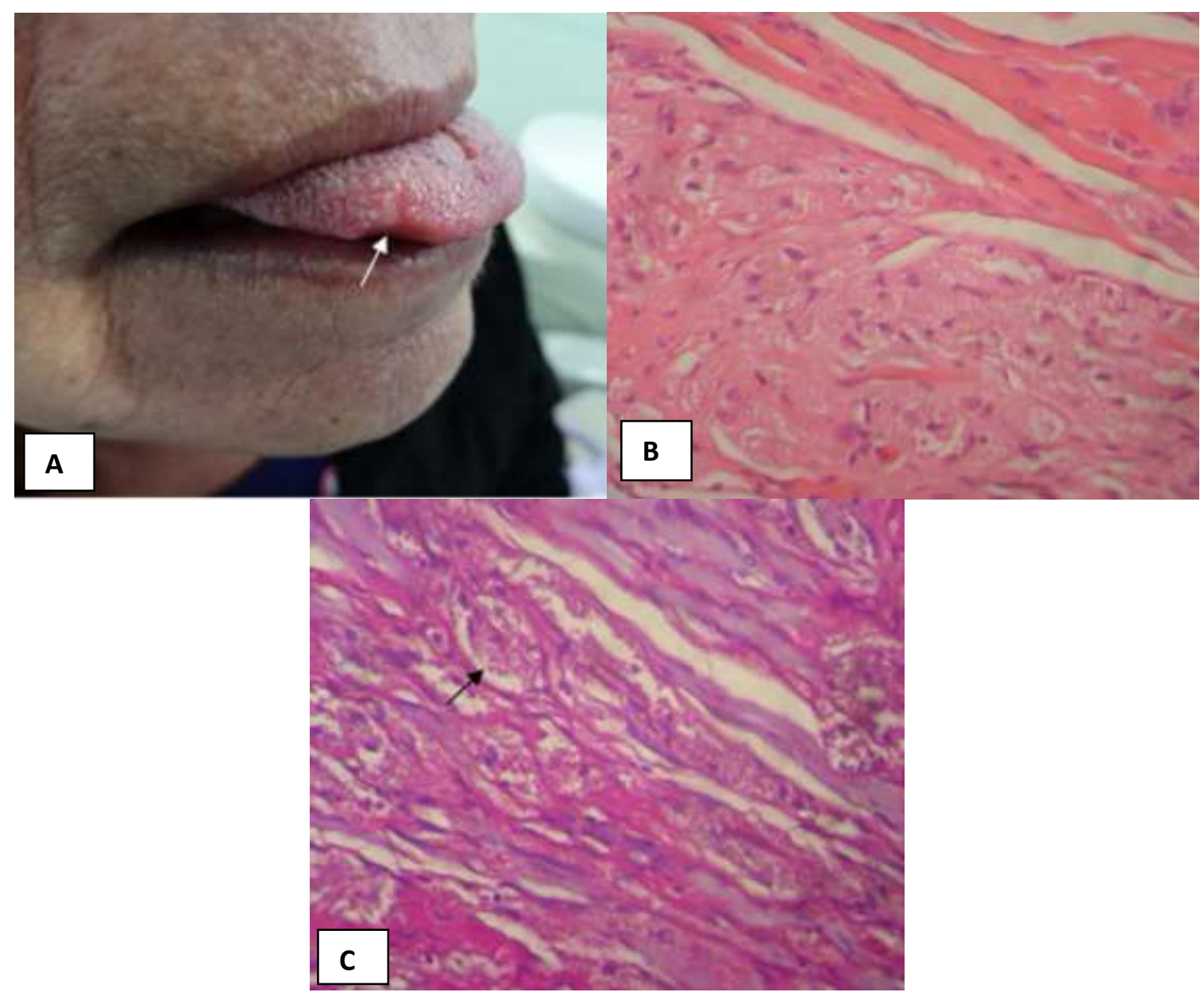

Source: Authors themselves.

\subsection{Case 2}

A 23-year-old female patient, Caucasian, attended the dental clinic for a routine dental examination and presented with a nodule with a progressive increase in size. The patient denied concurrent systemic or immunological diseases and denied being a smoker. The patient does not have a prosthesis or orthodontic appliance.

On clinical examination, the presence of a somewhat white-gray verrucous lesion was observed on the lateral border of the tongue, on the right, measuring approximately $1 \mathrm{~cm}$ in diameter. The patient reported that the lesion appeared approximately 4 years ago and that it was not associated with any trauma of the region. The clinical impression was fibroma.

Surgical excision of the lesion was performed, and the specimen was sent for anatomopathological examination. The product of the excision, on macroscopic examination, was described as a spindle of thick, creamy mucosa. Under microscopy, histological sections showed epithelium with discrete parakeratosis, irregular acanthosis with epidermal crest elongation and an accumulation of numerous xanthomatous macrophages in the connective tissue (Figure 3A and 3B). Findings suggestive of human papillomavirus (HPV) infection, such as hypergranulosis or koilocytosis, were not observed in the initial biopsy. PAS (periodic acid-Schiff) staining showed diastase-resistant granules in the cytoplasm of macrophages (Figure 3C). The diagnosis was compatible with verruciform xanthoma, with free surgical margins. 
Figure 3. Histological features - Case 2. A - Epithelium with irregular acanthosis and elongation of crests and accumulation of xanthomatous macrophages in the tissue (hematoxylin-eosin, 100x magnification). B - Accumulation of numerous xanthomatous macrophages in the connective tissue (hematoxylin-eosin, 400x magnification). C - Note PAS-positive, diastaseresistant granules in the cytoplasm of the macrophages (arrow) (PAS with diastase, 400x magnification).

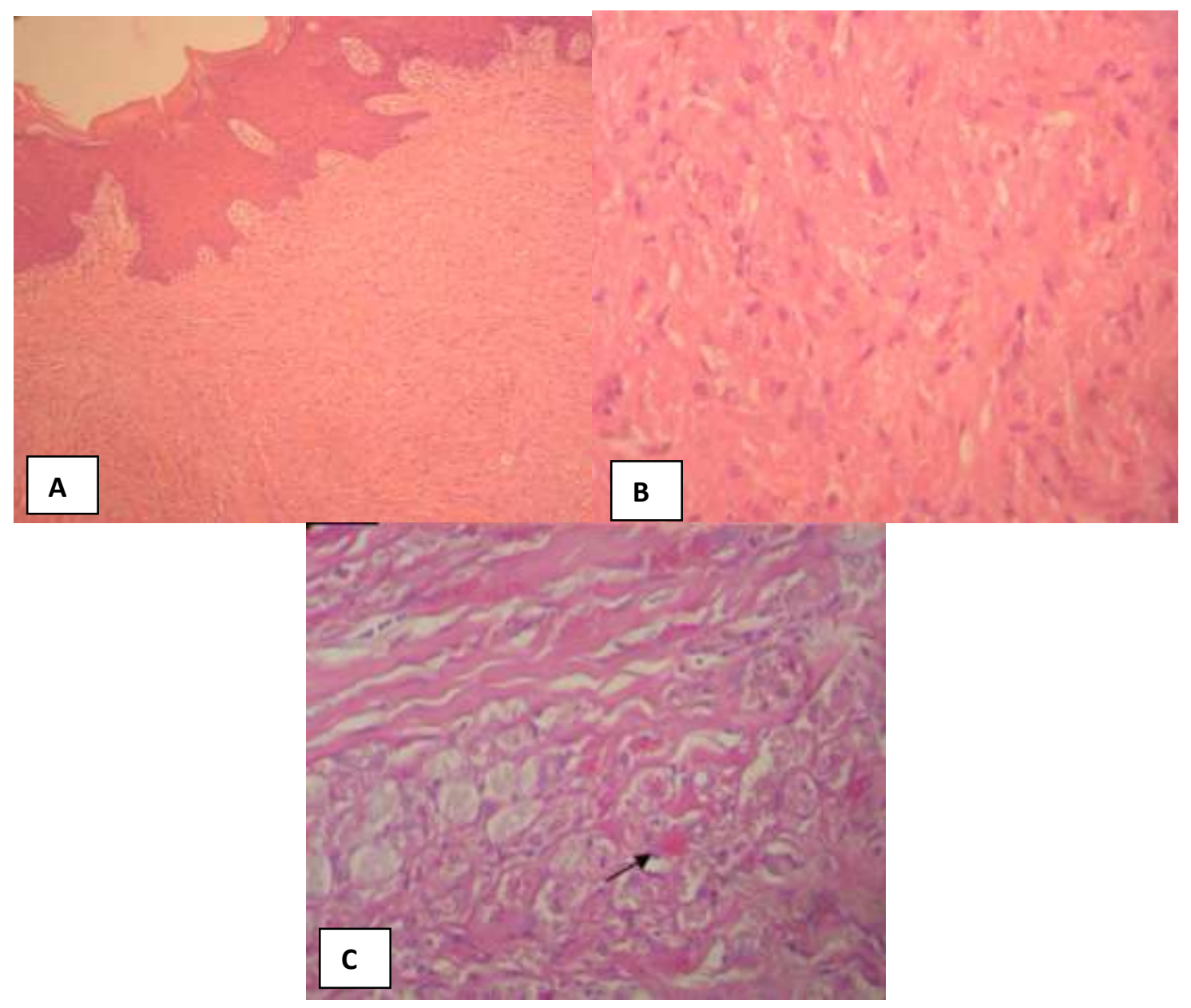

Source: Authors themselves.

One year after removal of the lesion, the patient has not had any recurrence.

\section{Discussion}

Oral verruciform xanthoma is more common in the masticatory mucosa, hard palate, tongue, buccal floor, alveolar mucosa and soft palate (Dorankula et al., 2013; de Andrade et al., 2015). It measures approximately $2 \mathrm{~mm}$ to $1.5 \mathrm{~cm}$, being asymptomatic in most cases (Dorankula et al., 2013; Hegde et al., 2013; de Andrade et al., 2015). In cases with symptomatology, the patient may complain of local burning (Aggarwall et al., 2014). In the present report, both lesions were localized to the tongue, and one of the patients presented with burning and the other with pain associated with the nodule appearance. At variance with the cases reported in the literature is that in the present study, one of the lesions was much larger than those previously described. This shows that even with larger lesions, verruciform xanthoma must be included in their differential diagnoses.

Clinically, verruciform xanthoma may present as a single-color plaque varying from reddish pink to a slowly developing gray color, and may have a differential diagnosis of squamous papilloma, verrucous hyperplasia, verrucous carcinoma, squamous cell carcinoma, leukoplakia, verruca vulgaris and seborrheic keratosis. Studies show that half of the 
cases are associated with a clinical diagnostic impression of papilloma, followed by squamous cell carcinoma, leukoplakia and verrucous carcinoma (Shahrabi Farahani et al., 2011; de Andrade et al., 2015). In the reported cases, the clinical hypotheses were leukoplakia in the first case and fibroma in the second. The size of the lesion (4 cm in largest axis) and its appearance (a somewhat verrucous and grayish-white lesion) probably contributed to the clinical hypothesis of leukoplakia in the first case, and the nodular aspect likely led to the clinical hypothesis of fibroma in the second case. This shows that the clinical diagnosis of verruciform xanthoma is difficult because it can mimic several benign or malignant lesions of the oral cavity.

The diagnosis of oral verruciform xanthoma is informed by the clinical appearance, but in most cases, it is also necessary to perform a histopathological examination to distinguish it from other verrucous lesions (Shetty et al., 2013; Aggarwall et al., 2014). Exfoliative cytology, although unable to determine the diagnosis of verruciform xanthoma, can be performed to exclude malignancy in these lesions (Onda et al., 2018). Histologically, verruciform xanthoma is a verrucous acanthotic lesion with elongated and deep epithelial crypts and parakeratosis, and the main diagnostic feature is the presence of xanthomatous cells within the connective tissue (Shahrabi Farahani et al., 2011; de Andrade et al., 2015; Rush \& Bennett 2015). However, not all lesions of verruciform xanthoma have numerous xanthomatous macrophages that can be distinguished at the lowest magnification. The finding of a verrucous lesion at the lowest power that is highly orangeophilic should call attention to the fact that the papillary dermis or the submucosa must be evaluated at a higher power (Rush \& Bennett 2015). Based on epithelial changes, verruciform xanthomas can be classified as verrucous, papillary or flat, and these changes reflect the clinical characteristics of the lesion (Joshi \& Ohval, 2012). In the two cases reported in this study, the large number of xanthomatous macrophages in the submucosa, in addition to the characteristic epithelial alterations, facilitated the diagnosis without great difficulty.

Although its histopathological appearance is similar to the structure of lesions associated with the human papilloma virus (HPV), there is no evidence that HPV causes verruciform xanthoma (Shetty et al, 2013; Aggarwall et al., 2014). Ultrastructural and in situ hybridization analysis showed negativity for HPV in verruciform xanthomas, ruling out the hypothesis of the association of this lesion with the virus (Sah et al., 2008).

The etiopathogenesis of verruciform xanthoma is unclear; however, studies indicate that most cases should be associated with an immune mechanism to local trauma or chronic irritation (Hedge et al., 2013; Aggarwall et al., 2014; Marques et al., 2014), while other cases may be associated with a mutation in the NSDHL (steroid dehydrogenase NAD [P]) gene that encodes the enzyme for cholesterol synthesis, 3b-hydroxysteroid dehydrogenase (Tang et al., 2014).

Patients with verruciform xanthoma may have associated systemic or metabolic diseases, such as lymphedema, pemphigus vulgaris, lichen planus, lipid accumulation diseases, epidermolysis bullosa or CHILD (congenital hemidysplasia with ichthyosiform erythroderma and limb defects) syndrome. This association with numerous diseases suggests that verruciform xanthoma is a reactive phenomenon (Tang et al., 2014). Thus, colonization by microorganisms, traumas, genetic predisposition and inflammation may play a role in the formation of verruciform xanthoma. However, unlike other xanthomatous disorders, there is no association with altered lipid metabolism (Tang et al., 2014). Although verruciform xanthoma may be associated with systemic or metabolic diseases, it is apparently not associated with environmental factors, such as cigarette smoking, alcoholism or the use of oral prostheses (Ryu et al., 2013). In the present case, the patients did not present systemic or metabolic diseases; however, one was smoker and had an oral prosthesis. The presence of the oral prosthesis may have been the causal factor for the appearance of verruciform xanthoma in the first case, as it led to local chronic trauma. In the second case, the patient did not relate the appearance of the lesion to trauma and, as she had no other risk factors, the possible cause of the lesion cannot be determined.

Some authors have suggested that the accumulation of xanthomatous macrophages is the first event in the formation of verruciform xanthoma and that epidermal hyperplasia and inflammation are secondary. Local chronic irritation or trauma 
would lead to epidermal degeneration and keratinocyte lipids would be phagocytosed by submucosal and dermal macrophages (Mohsin et al., 1998; Tang et al., 2014). In addition, after epithelial damage, neutrophil chemotactic factors would be released, stimulating rapid epidermal growth resulting in a verruciform architecture and parakeratosis (Mohsin et al., 1998).

The treatment of choice of verruciform xanthoma is complete local surgical excision, which almost always presents curative results. Other clinical, pharmacological or radiological treatments are not necessary after surgical excision (Ryu et al., 2013). Recurrence of the lesion is rare (Shahrabi Farahani et al., 2011; Shetty et al., 2013; Aggarwall et al., 2014), as is malignant transformation (Ryu et al., 2013). In one of the cases reported in the present study, the lesion was not completely excised (it had compromised surgical margins), and the patient presented with recurrence after three years of follow-up. At the re-excision of the lesion, numerous xanthomatous macrophages were observed in the connective tissue, which was compatible with residual verruciform xanthoma. The other patient, who had lesion-free surgical margins, did not recur. These findings demonstrate that total excision of the lesion is necessary for curative treatment of this pathology since the presence of a residual lesion may lead to recurrence.

\section{Conclusion}

Although it is an uncommon lesion, verruciform xanthoma should be considered in the differential diagnosis of verrucous (benign and malignant) lesions of the oral cavity, and total excision is important to prevent recurrence of this lesion.

Future studies carried out in case series and with molecular evaluation of verruciform xanthomas may better clarify its etiology.

\section{Acknowledgments}

This study was funded with financial aid by Universidade do Oeste Paulista.

\section{References}

Aggarwall, S., Aggarwal, A., Gill, S., Bakshi, Y., Singh, H. P. (2014). Verruciform Xanthoma of Oral Cavity- A Case Report. Journal of Clinical and Diagnostic Research, 8(7), 11-12.

Bar, O., Elad, S., Avni, B., Abu-Tair, J., Zaharia, B., Hanut, A., \& Zadik, Y. (2021). Oral verruciform xanthoma in chronic graft-versus-host disease patients. Supportive care in cance : official journal of the Multinational Association of Supportive Care in Cancer,29(1), 79-84. https://doi.org/10.1007/s00520-020-05681-w

Belknap, A. N., Islam, M. N., Bhattacharyya, I., Cohen, D. M., \& Fitzpatrick, S. G. (2020). Oral Verruciform Xanthoma: A Series of 212 Cases and Review of the Literature. Head and neck pathology, 14(3), 742-748. https://doi.org/10.1007/s12105-019-01123-0

de Andrade, B. A., Agostini, M., Pires, F. R., Rumayor, A., Carlos, R., de Almeida, O. P., \& Romañach, M. J. (2015). Oral verruciform xanthoma: a clinicopathologic and immunohistochemical study of 20 cases. Journal of cutaneous pathology, 42(7), 489-495. https://doi.org/10.1111/cup.12500

Dorankula, S. P., Ramani, P., Premkumar, P., Anuja, \& Sherlyn, H. J. (2013). Verruciform xanthoma of the oral cavity - a case report. Journal of clinical and diagnostic research: JCDR, 7(8), 1799-1801. https://doi.org/10.7860/JCDR/2013/6559.3309

Hegde, U., Doddawad, V. G., Sreeshyla, H., \& Patil, R. (2013). Verruciform xanthoma: A view on the concepts of its etiopathogenesis. Journal of oral and maxillofacial pathology: JOMFP, 17(3), 392-396. https://doi.org/10.4103/0973-029X.125205

Jenkyn, I., Woodward, G., Kelly, A., \& Fowell, C. (2020). Oral verruciform xanthoma associated with stem cell transplantation and graft versus host disease in a paediatric patient. Bone marrow transplantation, 55(9), 1832-1833. https://doi.org/10.1038/s41409-019-0772-1

Joshi, R., \& Ovhal, A. (2012). Verruciform xanthoma: report of five cases. Indian journal of dermatology, 57(6), 479-482. https://doi.org/10.4103/00195154.103069

Kienle, G. S., \& Kiene, H. (2009). Methodik der Einzelfallbeschreibung. Der Merkurstab, 62(3), 239-242.

Liddell, C., \& Plantier, F. (2021). Un xanthome verruciforme vulvaire [A vulvar verruciform xanthoma]. Annales de pathologie, S0242-6498(20)30282-0. Advance online publication. https://doi.org/10.1016/j.annpat.2020.12.006

Marques, Y. M., de Andrade, C. R., Machado de Sousa, S. C., \& Navarro, C. M. (2014). Oral verruciform xanthoma: a case report and literature review. Case reports in pathology, 2014, 641015. https://doi.org/10.1155/2014/641015 
Research, Society and Development, v. 11, n. 1, e53411125315, 2022

(CC BY 4.0) | ISSN 2525-3409 | DOI: http://dx.doi.org/10.33448/rsd-v11i1.25315

Mohsin, S. K., Lee, M. W., Amin, M. B., Stoler, M. H., Eyzaguirre, E., Ma, C. K., \& Zarbo, R. J. (1998). Cutaneous verruciform xanthoma: a report of five cases investigating the etiology and nature of xanthomatous cells. The American journal of surgical pathology, 22(4), 479-487. https://doi.org/10.1097/00000478-199804000-00014

Onda, T., Hayashi, K., Shiraishi, N., Takano, N., \& Shibahara, T. (2018). Verruciform Xanthoma with Equivocal Exfoliative Cytological Diagnosis. The Bulletin of Tokyo Dental College, 59(3), 193-200. https://doi.org/10.2209/tdcpublication.2017-0034

Rush, P. S., \& Bennett, D. D. (2016). The wart on fire. Journal of cutaneous pathology, 43(3), 293-294. https://doi.org/10.1111/cup.12628

Ryu, D. J., Lee, S. H., Yuk, J. I., Kim, H. J., Huh, J. K., \& Park, K. H. (2013). Verruciform xanthoma of the palatal gingiva: a report of two cases. Journal of the Korean Association of Oral and Maxillofacial Surgeons, 39(6), 292-296. https://doi.org/10.5125/jkaoms.2013.39.6.292

Sah, K., Kale, A.D., Hallikerimath, S. (2008). Verruciform xanthoma: Report of two cases and review on pathogenesis. Journal of Oral and Maxillofacial Pathology, 12, 41-44.

Shahrabi Farahani, S., Treister, N. S., Khan, Z., \& Woo, S. B. (2011). Oral verruciform xanthoma associated with chronic graft-versus-host disease: a report of five cases and a review of the literature. Head and neck pathology, 5(2), 193-198. https://doi.org/10.1007/s12105-011-0246-2

Shetty, A., Nakhaei, K., Lakkashetty, Y., Mohseni, M., \& Mohebatzadeh, I. (2013). Oral verruciform xanthoma: a case report and literature review. Case reports in dentistry, 2013, 528967. https://doi.org/10.1155/2013/528967

Tamiolakis, P., Theofilou, V. I., Tosios, K. I., \& Sklavounou-Andrikopoulou, A. (2018). Oral verruciform xanthoma: Report of 13 new cases and review of the literature. Medicina oral, patologia oral y cirugia bucal, 23(4), e429-e435. https://doi.org/10.4317/medoral.22342

Tang, R., Kopp, S. A., Cobb, C., \& Halpern, A. V. (2014). Disseminated verruciform xanthoma: a case report. Cutis, 93(6), 307-310. 